\title{
Penguatan kapasitas kelembagaan gapoktan melalui pembentukan koperasi pertanian
}

\section{Gapoktan capacity institutionalization through farmer cooperative (koperasi)}

\author{
Fitriani \\ Jurusan Ekonomi dan Bisnis, Politeknik Negeri Lampung, Lampung \\ Jalan Soekarno-Hatta No.10, Bandar Lampung, Provinsi Lampung, Indonesia \\ E-mail: fitriani@polinela.ac.id
}

\begin{abstract}
Gapoktan or Farmers Group constructed with focus on improving agricultural production. Gapoktan generally faces problems such as limited access to capital, technology and markets. A lack of communication and coordination between the farmer and board member Gapoktan also cause ineffectiveness in Gapoktan performance. This study aims to identify the fusion process and consolidation of institutions Gapoktan become new economic institutions as agricultural cooperatives, also to discover the prerequisite conditions and the necessary support in the new cooperative institutions manifest in District Adiluwih. Methods RRA (rapid rural appraisal) and FGDs conducted to produce concrete solutions for Gapoktan institutional problem resolution. Literacy exploration was an important part in analyzing the problems solving. The finding concluded that the fusion of Gapoktan to cooperative institution took place gradually. The new cooperative called LKMA Sharia Adi Makmur Cooperation. Internal consolidation in Gapoktan board continued with the preparation of cooperative establishment. Furthermore, a new cooperative members meeting, registration at the Notary, and the filing of a legal entity were the process of the cooperative establishment. Prerequisite condition for cooperative operation was the good financial and managerial performances. Supporting conditions was necessary for cooperative performance. Conducive business circumstance on cooperative core business was needed. Strengthening cooperative networking with strategic partners was the main factor to increase the capacity of the cooperative effort.
\end{abstract}

Keywords: cooperative, capacity, Gapoktan, agriculture institution, management

\begin{abstract}
Abstrak
Gapoktan atau Gabungan Kelompok Tani dibangun dengan tujuan fokus pada peningkatan produksi pertanian. Gapoktan secara umum menghadapi persoalan keterbatasan akses modal, teknologi, dan pasar. Kurangnya komunikasi dan koordinasi antara petani anggota dan pengurus Gapoktan juga menjadi penyebab kinerja Gapoktan tidak optimal. Studi ini bertujuan untuk mengidentifikasi proses fusi dan konsolidasi lembaga Gapoktan menjadi lembaga ekonomi baru koperasi pertanian. Juga menelusuri kondisi prasyarat dan pendukung yang diperlukan dalam mewujudnya lembaga koperasi baru di Kecamatan Adiluwih. Metode RRA (rapid rural appraisal) dan FGD dilakukan untuk menghasilkan solusi konkret penyelesaian masalah kelembagaan Gapoktan. Penelusuran terhadap literasi yang mendukung menjadi bagian penting dalam menganalisis permasalahan yang dihadapi. Berdasarkan hasil pembahasan disimpulkan bahwa proses fusi Gapoktan membentuk organisasi baru, Koperasi LKMA Syariah Adi Makmur berlangsung secara bertahap. Konsolidasi internal dalam kepenguusan Gapoktan dilanjutkan dengan persiapan rapat pendirian. Selanjutnya dilakukan Rapat Anggota pendirian koperasi baru, pendaftaran akta pendirian di Notaris, dan pengajuan badan hukum. Kondisi prasyarat bekerjanya koperasi dengan baik adalah performa manajerial keuangan dan organisasi koperasi. Kondisi pendukung kinerja koperasi adalah iklim usaha yang kondusif. Penguatan jejaring koperasi dengan mitra strategis menjadi kunci keberhasilan koperasi dalam meningkatkan kapasitas usaha.
\end{abstract}

Kata kunci: koperasi, kapasitas, Gapoktan, manajerial

\section{Pendahuluan}

Gapoktan atau Gabungan Kelompok Tani dibangun dengan tujuan fokus pada peningkatan produksi pertanian. Menurut UU No. 19 tahun 2013 tentang perlindungan dan pemberdayaan petani Gapoktan adalah kumpulan beberapa Kelompok Tani yang bergabung dan bekerja sama untuk meningkatkan 
skala ekonomi dan efisiensi usaha. Efisiensi produksi dan produktivitas usahatani menjadi prasyarat peningkatan pendapatan dan kesejahteraan petani di tingkat perdesaan.

Efisiensi produksi dapat dicapai melalui kombinasi input secara optimum dalam usahatani. Pemenuhan input usahatani sangat tergantung pada kemudahan akses permodalan untuk usaha pertanian. Ketersediaan modal untuk kegiatan usahatani menjadi prasyarat dasar terselenggaranya kegiatan usahatani dalam setiap musim tanam.

Petani yang terorganisasi dalam kelembagaan Gapoktan akan mencapai tujuan pemberdayaan dan penguatan petani sebagai kekuatan ekonomi yang lebih sejahtera (Fitriani dkk 2011). Performa kinerja kelembagaan secara optimal berkontribusi secara positif dalam penyelesaian kompleksitas persoalan pertanian yang dihadapi anggotanya. Pencapaian tujuan utama kelembagaan yaitu pemberdayaan petani sebagai pelaku ekonomi. Berdaya secara ekonomi, berarti petani memiliki akses yang kuat dalam permodalan, pengelolaan usahatani, dan memiliki tingkat pendapatan dan kesejahteraan setara dan berkeadilan dengan pelaku ekonomi lainnya (Sutarni dan Fitriani 2013).

Penyebab lemahnya kinerja kelembagaan secara umum adalah keterbatas akses modal, teknologi, dan pasar. Kurangnya komunikasi dan koordinasi antara petani anggota dan pengurus Gapoktan juga menjadi penyebab kinerja Gapoktan tidak optimal. Kerjasama anggota kelompok tani dalam penyediaan sarana/input produksi pertanian rendah karena sebagian besar petani tidak memiliki akses dalam pengadaan cash money untuk pembelian input. Kurangnya kerjasama anggota dalam aktivitas budidaya, sehingga petani melakukan budidaya sendiri-sendiri sesuai dengan pengalamannya (Juraemi 2004).

Berdasarkan permasalahan kelembagaan di atas, strategi penting penguatan kapasitas lembaga Gapoktan adalah melakukan fusi membentuk lembaga ekonomi baru. Lembaga ekonomi dan keuangan mikro agribisnis dapat menjadi peran baru bagi Gapoktan dan kelompok tani.

Lembaga ekonomi dan keuangan mikro agribisnis merupakan bagian integral dalam pelaksanaan kebijakan revitalisasi pertanian dan rencana strategis pembangunan pertanian melalui upaya pengelolaan keuangan oleh kelompok tani dan Gapoktan. Kelembagaan usaha yang mengelola jasa keuangan untuk membiayai usaha skala mikro baik berbentuk formal maupun non formal di bidang pertanian dapat diprakarsai oleh masyarakat atau pemerintah.

Wujud formal lembaga ekonomi dan keuangan mikro agribisnis adalah koperasi. Koperasi merupakan lembaga ekonomi kerakyatan yang diamanatkan UUD 1945. Lembaga ekonomi koperasi berfungsi membangun dan mengembangkan potensi dan kemampuan ekonomi anggota untuk meningkatkan kesejahteraan ekonomi dan sosialnya; Peningkatan kualitas kehidupan masyarakat hanya dapat ditempuh melalui peningkatan pendapatan dan berkembangnya perekonomian rakyat sebagai dasar kekuatan dan ketahanan perekonomian wilayah.

Kunci keberhasilan koperasi terletak pada kesungguhan pengurus dalam melakukan prinsip-pinsip organisasi ekonomi yang sehat, transparan dan akuntabel. Sebagai lembaga koperasi baru persoalan yang dihadapi tidak sederhana. Tingkat pengetahuan yang beragam, belum solidnya kerjasama dan saling percaya di antara anggota dan pengurus, transparansi dan akuntabilitas pengelolaan koperasi menjadi masalah penting yang perlu mendapatkan solusi.

Keterbatasan modal usaha dalam layanan pembiayaan ke anggota yang semakin meningkat juga menjadi hambatan dalam operasional jasa pembiayaan koperasi. Koperasi perlu memikirkan sumbersumber tambahan modal.

Kecamatan Adiluwih merupakan salah satu dari 8 kecamatan di Kabupaten Pringsewu. Seiring dengan tuntutan perkembangan struktur ekonomi dan pemerintahan desa, pada awal tahun 2012, Desa Adiluwih mengalami pemekaran menjadi tiga desa, yaitu Desa Adiluwih, Desa Srikaton, dan Desa Tunggul Pawenang. Konsekuensi dari perubahan struktur pemerintahan desa tersebut, menyebabkan 
kelembagaan pertanian yang ada di tingkat desa, yaitu Gapoktan dan kelompok tani juga turut mengalami perubahan.

Gapoktan yang ada di Desa Adiluwih pada awalnya adalah Gapoktan Sumber Makmur pada tahun 2007, dengan register Deptan tahun 2008. Tahun 2010 Desa Tunggul Pawenang memiliki Gapoktan Jaya Makmur pada tahun 2011. Komunikasi dan konsolidasi sesama Gapoktan dalam lingkup Kecamatan Adiluwih menjadi salah satu wahana dalam meningkatkan kapasitas kelembagaan.

Gapoktan berperan sebagai sumber informasi perkembangan teknologi di bidang pertanian, Gapoktan juga memfasilitasi kemudahan petani dalam mendapatkan sarana produksi pertanian, meskipun masih terbatas.

Secara umum, Gapoktan Sumber Makmur dan Gapoktan Jaya Makmur masih menghadapi keterbatasan kapasitas kelembagaan, terutama pada aspek permodalan, pengadaan sarana produksi, adopsi teknologi baru, dan akses pemasaran.

Studi ini bertujuan untuk mengidentifikasi proses fusi dan konsolidasi lembaga Gapoktan menjadi lembaga ekonomi baru koperasi pertanian. Juga menelusuri kondisi prasyarat dan pendukung yang diperlukan dalam mewujudnya lembaga koperasi baru di Kecamatan Adiluwih.

\section{Metode Penelitian}

Pelaksanaan kegiatan fusi Gapoktan menjadi koperasi berlangsung selama 8 bulan dari Mei s.d. November 2014. Berlokasi di Kecamatan Adiluwih Kabupaten Pringsewu, Propinsi Lampung. Berdasarkan permasalahan yang dihadapi, pendekatan kelompok dengan metode RRA (rapid rural appraisal) dan FGD dirumuskan untuk menghasilkan solusi konkret untuk menyelesaikan masalah kelembagaan Gapoktan. Penelusuran terhadap literasi yang mendukung menjadi bagian penting dalam menganalisis permasalahan yang dihadapi.

\section{Hasil dan Pembahasan}

\section{Proses fusi Gapoktan menjadi koperasi}

Kecamatan Adiluwih secara umum mengembangkan usaha produktif di sektor pertanian dan perdagangan. Sektor pertanian unggulan adalah tanaman pangan, hortikultura, perkebunan, dan peternakan.

Berdasarkan Focus Group Discussion (FGD) Gapoktan di Kecamatan Adiluwih diketahui bahwa persoalan utama yang masih dihadapi dalam pengembangan usaha di bidang pertanian mengerucut pada tingginya risiko kegagalan usahatani akibat serangan OPT (organism pengganggu tanaman) dan gangguan iklim yang menimbulkan kerugian. Selain juga masih menghadapi ketidakpastian harga jual. Pada sisi lain, usahatani juga menghadapi kekurangan modal usaha terutama pada waktu musim tanam untuk pengadaan input sarana produksi pertanian.

Secara umum, pertanian di perdesaan masih menghadapi masalah adalah produktivitas yang rendah akibat keterbatasan modal dalam pengadaan input produksi dan akses teknologi, selain juga masih menghadapi persoalan harga produksi yang tidak kompetitif (Fitriani dan Sutarni 2011, Fitriani dkk 2011, Fatih 2007,dan Fatih 2002). Persoalan tersebut berdampak pada tingkat pendapatan dan kesejahteraan petani di perdesaan.

FGD pada tanggal 25 September 2013 tersebut dihadiri 30 anggota Gapoktan dan kelompok tani merumuskan alternatif solusi persoalan teknologi budidaya dan penanganan gangguan OPT dan iklim melalui komunikasi yang intensif antara anggota dengan pengurus kelompok/Gapoktan dan tenaga teknis (PPL/THL) dari UPTD Dinas Pertanian dan BP4K Kecamatan secara simultan dan 
berkelanjutan. Selama ini, persoalan keterbatasan sumberdaya di BP4K masih menjadi hambatan. Jadwal kunjungan, luasnya wilayah binaan, kurangnya tenaga penyuluh, juga hambatan transportasi menjadi restriksi tenaga teknis lapang dalam mendampingi lembaga tani. Optimalisasi pemanfaatan media melalui jejaring telekomunikasi menjadi solusi mudah dan murah yang bisa dimanfaatkan Gapoktan secara proaktif dalam menyelesaikan persoalan teknis.

Sementara, untuk masalah penguatan modal bersama/kelompok untuk mengatasi kekurangan modal anggota/petani, melalui penggalangan secara akumulatif kekuatan lembaga pertanian di desa menjadi langkah awal kerjasama yang lebih luas dalam usaha meningkatkan skala ekonomi keuangan lembaga pertanian. Gapoktan saling bekerjasama membentuk kelembagaan ekonomi menjadi koperasi pertanian. Koperasi pertanian dapat mengatasi persoalan keterbatasan modal dalam pengelolaan usaha pertanian. Prawirosentono (2002) menjelaskan modal sebagai kekayaan yang dimiliki perusahaan yang dapat menghasilkan keuntungan pada waktu yang akan datang dan dinyatakan dalam bentuk uang. Setiap usaha bisnis memerlukan modal, baik modal sendiri maupun modal pinjaman. Modal sendiri (equity capital) seringkali tidak mencukupi kebutuhan modal keseluruhan yang diperlukan untuk mengoperasikan perusahaan. Oleh karena itu, umumnya diperlukan modal pinjaman (debt capital). Mekanisme pengajuan permodalan/pembiayaan (Bank Syariah Mandiri (BSM) 2008) yang pertama dilakukan adalah analisis kelayakan berdasarkan aspek 5C (Character, Capacity, Capital, Condition, Collateral) atau 7 A (Aspek Legalitas, Manajemen, Teknis/Produksi, Pemasaran, Keuangan, Jaminan dan Resiko) dan kesesuaian dengan kaidah Syariah.

Peningkatan keterampilan manajerial pengelolaan koperasi menjadi kunci penting berjalannya fungsi koperasi. Dua kelembagaan Gapoktan (Sumber Makmur dan Jaya Makmur) bersepakat meningkatkan skala usaha. Peningkatkan skala usaha Gapoktan berbentuk koperasi pertanian. Upaya pendirian koperasi pertanian berbadan hukum dilakukan secara bertahap.

Kepengurusan kedua Gapoktan melakukan rapat persiapan pendirian koperasi (15 orang). Agenda utama menyepakati kriteria pemilihan anggota pendiri. Anggota pendiri diutamakan memiliki tingkat semangat untuk maju (progresif), proaktif, dan berintegritas. Rapat pendirian koperasi dihadiri minimal 20 anggota pendiri awal, masing-masing dengan proporsi sama antara Gapoktan Sumber Makmur dan Gapoktan Jaya Makmur.

Selain itu, kriteria pengurus koperasi, yang penting adalah: jujur, bertanggung jawab, pekerja keras, terampil berkomunikasi dan dapat bekerja sama, terampil menggunakan teknologi informasi (TI) serta memiliki integritas tinggi untuk mengembangkan dan memajukan koperasi juga menjadi agenda. Juga rencana simpanan pokok dan simpanan sukarela anggota.

Rapat rintisan pendirian koperasi dilakukan pada tanggal 20 Oktober 2013 dengan notulensi penentuan nama koperasi, penetapan pengurus, badan pengawas, simpanan pokok, dan sukarela koperasi. Berita acara pendirian koperasi yang disepakati bernama Koperasi LKMA Syariah Adi Makmur selanjutnya dijadikan dasar akta pendirian koperasi ke notaris yang berwenang. Syarat-syarat yang diperlukan untuk pendirian badan hukum koperasi berkonsultasi dengan Dinas Koperindag dan UMKM Kabupaten Pringsewu. Pada waktu itu, pengajuan badan hukum koperasi dilakukan secara manual ke Dinas Koperindag dan UMKM Kabupaten Pringsewu. Namun, saat ini, pendaftaran badan hukum dapat dilakukan secara online.

Rapat Anggota (RAT) awal merupakan pertemuan anggota pendiri koperasi untuk melakukan pemilihan kepengurusan, badan pengawas, dan pembahasan anggaran dasar (AD/ART) koperasi. Koperasi LKMA Adi Makmur didirikan berdasarkan Akta Pendirian No. 188 tanggal 27 Januari 2014. Izin Badan Hukum diperoleh dari Dinas Koperindag dan UMKM Kabupaten Pringsewu dengan No. 016/BH/X.12/II/2014 tanggal 5 Februari 2014.

\section{Kondisi prasyarat dan pendukung kinerja koperasi}

Kondisi prasyarat diperlukan untuk bekerjanya koperasi secara optimal. Penguasaan keterampilan manajemen keuangan dan manajerial organisasi koperasi menjadi kondisi awal yang perlu dilakukan. 
Pengetahuan dan keterampilan manajemen keuangan bagi pengurus koperasi menjadi indikator keberhasilan pengelolaan keuangan koperasi secara transparan dan akuntabel. Pencatatan dan pelaporan operasional koperasi dilakukan mulai dari transaksi akad, pencatatan dalam form jurnal, penyusunan penerimaan dan pengeluaran kas hingga ke pelaporan posisi keuangan. Keberlanjutan usaha koperasi di masa depan sangat tergantung pada keberhasil pengelolaan keuangan oleh pengurus koperasi. Indikator yang menjadi prasyarat tercapainya tujuan pembentukan koperasi dapat dilihat pada Tabel 1.

Tabel 1.

Indikator terpenuhinya prasyarat tujuan pembentukan koperasi

\begin{tabular}{|c|c|c|}
\hline Indikator & Sebelum & Setelah \\
\hline $\begin{array}{c}\text { Lembaga ekonomi } \\
\text { koperasi berbadan } \\
\text { hukum }\end{array}$ & $\begin{array}{l}\text { Belum } \\
\text { ada }\end{array}$ & Ada koperasi \\
\hline $\begin{array}{l}\text { Membangun modal } \\
\text { sosial melalui } \\
\text { pertemuan rutin } \\
\text { koperasi }\end{array}$ & $\begin{array}{l}\text { belum } \\
\text { ada }\end{array}$ & rutin dan berkala \\
\hline $\begin{array}{l}\text { Pengetahuan dan } \\
\text { keterampilan } \\
\text { manajemen }\end{array}$ & & \\
\hline $\begin{array}{l}\text { keuangan koperasi } \\
\text { Pengetahuan dan } \\
\text { keterampilan } \\
\text { manajemen }\end{array}$ & $0 \%$ & $60 \%$ \\
\hline organisasi koperasi & $0 \%$ & $60 \%$ \\
\hline
\end{tabular}

Prasyarat penting dalam kelangsungan organisasi koperasi adalah membangun modal sosial kelompok. Ridell (1997) menyatakan ada tiga parameter modal sosial, yaitu kepercayaan (trust), norma-norma (norms) dan jaringan-jaringan (networks). Membangun modal sosial koperasi dapat dilakukan melalui peningkatan pengetahuan bagi unsur-unsur koperasi, tercermin dari kepercayaan anggota dan pengurus, norma saling membantu dan menghargai serta membangun kerja sama dalam kelompok dan antar kelompok. Rasa saling percaya pada segenap unsur (pengurus dan anggota). Menyatukan kesamaan norma dan nilai yang dianut dalam pengelolaan koperasi. Menumbuhkan inisiasi peguatan jaringan kerjasama koperasi dengan lembaga lain (Fitriani et al. 2013).

Nilai-nilai yang seharusnya melekat pada organisasi kelembagaan koperasi adalah kemampuan untuk menolong diri sendiri, pengelolaan secara demokratis, berkeadilan, dan solidaritas, kepercayaan, dan bertanggung jawab/amanah. Nilai-nilai ini mengisyaratkan bahwa sebagai organisasi yang berkemampuan untuk menolong diri sendiri (selfhelp organization) harus memiliki tujuan ekonomi yang jelas dan manajemen kebersamaan (joint management) yang profesional. Oleh karena itu, membangun selalu modal sosial koperasi akan menjadi salah satu kunci penting terciptanya soliditas kelembagaan tani yang menyejahterakan masyarakat perdesaan.

Kunci keberhasilan dan pengembangan koperasi sangat tergantung kepada sinergi yang harmoni antara anggota dan kepengurusan yang credible dan accountable (Booth 2012, Munigar 2009, Santy 2008, dan Bennis et al. 1990). PERHEPI (2004) juga menghasilkan rekomendasi bahwa koperasi hanya akan berkembang apabila ada orang yang peduli dan menaruh perhatian kepada kepentingan hidup sesama karena koperasi adalah suatu metoda menjalankan bisnis yang modern dengan aturan main tidak sekedar bisnis.

Kondisi pendukung kinerja koperasi adalah iklim usaha yang kondusif. Penguatan jejaring koperasi dengan mitra strategis menjadi kunci keberhasilan koperasi dalam meningkatkan kapasitas usaha. Akses koperasi kepada lembaga perbankan, pembiayaan dan pelaku pasar menjadi lini bisnis yang 
strategis. Lembaga keuangan yang ada di Kecamatan Adiluwih dan Kabupaten Pringsewu meliputi Bank BRI, BNI, BCA, dan BPR.

Mitra bisnis pada pasar input dari berbagai perusahaan BUMN maupun swasta meliputi PT Pusri, PT Sangyang Sri, PT Petrokimia Gresik, Tanindo, Dupont, East West Seed, dan Pioneer. Pemerintah daerah hadir melalui Dinas Koperindag dan UMKM serta Dinas Pertanian. PTPN VII yang memiliki riwayat menyalurkan dana CSR kepada kelompok tani di Kecamatan Adiluwih ditambah beberapa perusahaan BUMN/Swasta potensial sebagai mitra ketiga penyedia sumber permodalan bagi koperasi.

Mitra strategis pada lini hilir perlu terus dikuatkan melalui jejaring distribusi hasil produksi anggota koperasi. Kepastian pasar dapat diawali dari rintisan sub terminal agribisnis produk unggulan sebagai unit usaha koperasi. Unit usaha ini sangat strategis dalam meningkatkan posisi tawar koperasi terhadap pelaku bisnis yang telah mapan di pasar. Keberhasilan kerjasama kemitraan koperasi dengan pelaku ekonomi lainnya ditentukan oleh sikap opportunistic, trust, reprocity (timbal balik), dan forbearance (sabar \& menahan diri) (Hendrayogi 2000).

Koperasi merupakan organisasi ekonomi yang perperan secara luas dalam meningkatkan kapasitas keuangan anggotanya. Melalui lembaga koperasi, petani dapat memenuhi tuntutan pasar seiring terjadinya transisi praktik pertanian tradisional ke pertanian komersial (Booth 2012). Pengembangan usaha agribisnis skala kecil perlu koperasi. Tanpa koperasi, tidak memungkinkan agribisnis kecil dapat berkembang menghadapi pengusaha besar (Lutfi 2011).

\section{Simpulan}

Proses fusi Gapoktan membentuk organisasi baru, Koperasi LKMA Syariah Adi Makmur berlangsung secara bertahap. Diawali dengan persiapan rapat pendirian, RAT pendirian koperasi baru, pendaftaran akta pendirian di Notaris, dan pengajuan badan hukum. Kondisi prasyarat bekerjanya koperasi dengan baik adalah performa manajerial keuangan dan organisasi koperasi. Kondisi pendukung kinerja koperasi adalah iklim usaha yang kondusif. Penguatan jejaring koperasi dengan mitra strategis menjadi kunci keberhasilan koperasi dalam meningkatkan kapasitas usaha.

\section{Daftar Pustaka}

Ancok D (2007) Outbond management Training: Aplikasi ilmu perilaku dalam pengembangan SDM. Yogyakarta: UII Press.

Bank Syariah Mandiri Bandar Lampung (2008) Peranan permodalan dan mekanisme pengajuan kredit. Makalah disampaikan dalam Kuliah Kewirausahaan Tingkat Lanjut di Politeknik Negeri Lampung. 28 Juli 2008. Bandar Lampung.

Bennis W dan Nanus B (1990) Kepemimpinan. strategi dalam mengemban tanggung jawab. Jakarta: Penerbit Erlangga.

Booth A (2012) Petani Lao perlu membentuk koperasi agar dapat memenuhi tuntutan pasar akan pangan. 24 Februari 2012. Kabar Hutan: Blog [Diakses 13 Maret 2014] http://blog.cifor.org/7550/pe.

Dewi G (2005) Aspek-aspek hukum dalam perbankan dan perasuransian syariah di Indonesia. Jakarta: Prenada Media.

Fatih C (2002) Analisis efisiensi pemasaran buncis di Desa Gisting atas kecamatan Talang Padang Kabupaten Tanggamus. Jurnal Penelitian Pertanian Terapan. Nomor 10.

Fatih C (2007) Efisiensi ekonomi dalam tataniaga kopi di Propinsi Lampung. Laporan Penelitian. Tidak dipublikasikan.

Fitriani, Sutarni, Yuniarti E, Fatih C (2013) IbM pada gapoktan di Kec. Adiluwih melalui peningkatan kapasitas kelembagaan membentuk kopeasi pertanian. Laporan IbM. Bandar Lampung: UPPM Polinela.

Fitriani dan Sutarni (2011) Penentuan skala usaha produksi ikan lele di Kabupaten Lampung Tengah. Jurnal Ilmiah ESAI. 5 (1) 
Fitriani, Noer I, Mulyana T, Sutarni, Irawati L (2011) Peningkatan kapasitas kelembagaan Gapoktan menjadi Lembaga Ekonomi Koperasi. Laporan PKM. UPPM Politeknik Negeri Lampung.

Fitriani, Untawati B, Mulyana T, Fatih C, dan Sutarni (2011) Penyuluhan pengolahan hasil dan pemasaran produk pertanian di Desa Mekarmukti Kecamatan Sekampung Kabupaten Lampung Timur. Laporan PKM. UPPM Politeknik Negeri Lampung.

Hendrojogy (2000) Koperasi. Azas-azas, teori dan praktik. Edisi Revisi 2000. Jakarta: PT RajaGrafindo Persada.

Juraemi (2004) Hubungan antara kinerja kelembagaan dengan keragaman sistem agribisnis pada perusahaan inti rakyat perkebunan kelapa sawit. Jurnal Ekonomi Pertanian dan Perikanan 1 (2):33-40.

Lutfi M (2011) Pemberdayaan koperasi berbasis agribisnis di daerah pedesaan.

Munigar ES (2009) Peran koperasi dalam mengembangankan sistem agribisnis belimbing dewa (Studi Kasus Pusat Koperasi Pemasaran Belimbing Dewa Depok Jabar) Departemen Agribisnis Fakultas Ekonomi dan Manajemen. IPB. Bogor.

PERHEPI (2004) Pembangunan perdesaan: Rekonstruksi kelembagaan ekonomi. http://www.smecda.com/e-book/Pembangunan_Perdesaan.pdf

Prawirosentono S (2002) Pengantar bisnis modern. studi kasus di Indonesia dan analisis kualitatif. Jakarta: PT Bumi Aksara.

Prijosaksono A dan Hartono P (2002) Make yourself a leader. Jakarta: PT Gramedia.

Riddell M (1997) Bringing back balance to policy development. In: Robinson D (ed) Social Capital and Policy Development. Wellington: Institute of Policy Studies.

Santy (2008) Analisis kinerja dan faktor-faktor yang mempengaruhi keanggotaan Koptan Mitra Suka Maju Desa Pasir Langu Kec. Cisarua, Bogor, Jabar. Skripsi, IPB, Bogor. 